\title{
Policy Implications Of The War In Iraq And Its Influence On The Global Market: A Public Affairs Perspective
}

Michael O. Adams, (E-mail: adams_mo@tsu.edu), Texas Southern University Gbolahan S. Osho, (E-mail: oshogs@tsu.edu), Texas Southern University

\begin{abstract}
United States coalition force invaded Iraq after months of failed negotiation with the United Nation Security Council and the Iraqi government. Many of the nations that opposed the invasion were important trading partners with the U.S. As such, global trade relationships have been damaged in the short run. This paper examines the impact of Iraqi war on the global market economy. The global market performance was sluggish in the weeks preceding the war and including the cessation of the war in Iraq. This was due to uncertainty in the price of oil and the ultimate outcome of the war. However, markets rebounded as oil prices normalized due to the quick overthrow of Baghdad. Furthermore, the U.S. dollar had been steadily weakening against the Euro in the months preceding the war. Therefore, a successful completion of the Iraq war will help prevent further devaluation of the dollar.
\end{abstract}

\section{INTRODUCTION}

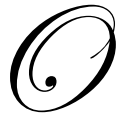

n March 20, 2003, after months of failed negotiations with the U.N. Security Council and the Iraqi government, a U.S. led coalition forces began its invasion of Iraq. The U.S. military were after Saddam Hussein. The wars started by the intense bombing of Iraq. The world watched with shock and awe as the events unfolded, culminating in the fall of the Iraqi government, just within four weeks after the conflict started. Despite considerable controversy, both critics and supporters were witness to one of the most successful military campaigns in the history of the world. But the question remains, did the U.S. really just win the battle, and actually lose the war?

War with Iraq introduced several negative factors into an already pessimistic domestic and global market, such as relationships with trade partners were strained, risk and uncertainty about the outcome of the war complicated the markets, and consumers lashed out against opposing national viewpoints with boycotts. Hence this paper examines the effects of the war with Iraq, on the global market economy with specific objective of the impact on international trade, financial markets and exchange rates.

Regardless of whether or not the rationale for invading Iraq was sound and just, several international and political relationships were damaged in the process. The list of countries with which the U.S. strained its political and financial ties includes France, Germany, Italy, Japan, and Russia. These countries account for a significant amount of the international trade of goods, services and financial investments crucial to the well being of the economy of the United States. In 2002 fiscal year, the U.S:

- $\quad$ Exports of Goods, Services and Income Receipts = 1,229,649

- $\quad$ Imports of Goods, Services and Income Payments = 1,651,657

- $\quad$ Net Unilateral Current Transfers $=-58,853$

- $\quad$ Net Current Account Balance $=-480,861$ 
For the 2002 fiscal year, the United States imported \$480,861 billion more than it exported. Although this deficit may seem like a substantial disparity in international trade balance, it is only one-half of the equation. According to the capital account figures for that same year, 2002, the U.S. had a $\$ 527,998$ billion surplus (includes statistical discrepancy of $\$ 45,852$ Billion) in foreign investment inflow (U.S. International Transactions, Table I).

There are two major lessons that should be taken from the figures above. First, the United States imports significantly more goods and services than it exports during the war. Second, the United States finances the current account deficit with a substantial amount of domestic investment from foreign investors. Overall, this makes the United States a net-importer of capital. This implies that the U.S. presents attractive investment opportunities to foreign investors because of open economic conditions, low perceived political risk, relatively low inflation risk, and effective monetary and fiscal policies.

However, the recent war in Iraq and the events both leading up to and following the war, are threatening to negate some of the characteristics that contribute to an attractive investment environment. Open trade is an important component of the U.S. economy. Damaged trade relations could seriously impact many U.S. based multinationals that both manufacture and sell their products abroad. Due to France's opposition to U.S. policy in Iraq, many U.S. consumers have called for a general boycott of French products. Considering the fact that France exports approximately $€ 1.71$ Billion in wine and spirits to the U.S. every year, this is a significant reduction in revenue (Graff, 2003).

Conversely, negative feelings toward the United States have also been running high in Europe, where the majority of Europeans felt that the war in Iraq was unjust and unnecessary. Many Europeans have been calling for boycotts of American goods and services, but it is unclear as to whether these incidents of protest have had any success. Howard Schultz, the chairman of Seattle based Starbucks claims that the scattered protests and boycotts have not significantly impacted the sales of its 1,500 stores abroad (Mandell, 2003).

Further complicating the damage done to international trade relations is the current contraction in the global market economy. The U.S. has been recovering from a prolonged recession. However, Japan and Germany are in or near recession, and the economies of Italy and France are sluggish. Deflation has become a real concern in the current economic climate. Additionally, trade disputes have arisen over U.S. duties on steel and subsidies to manufactured exports as well as European restrictions on genetically modified farm products (Tulacz and Powers, 2003).

In this age of globalization and multinational corporations, international economies are becoming increasingly interdependent. According to (Mandell, 2003) in the 1990's the U.S. invested about $\$ 750$ billion in capital abroad. In Europe, these U.S. affiliates produced about $\$ 333$ billion in goods and services in 2000. Conversely, European affiliates in the U.S. produced $\$ 301$ billion in goods and services. In today's global economy, where Japanese cars are produced in the U.S. and U.S. cars are produced in Mexico, trade relations are crucial to global economic growth and prosperity (Francis, 2003).

Due to growing technology, financial and economic news flows through telecommunications pipelines, gushing into every conceivable device ready to receive it. This overload of information may seem superfluous at times, but it also makes for incredibly efficient markets. Market prices fluctuate as quickly as the news about world or domestic events occur.

A huge component of financial market health is consumer and business expectations. The war in Iraq affects the stock markets because a short run increase in oil prices with possible lingering long run effects, increased government borrowing due to increased military spending, damaged relations with trading partners, increased terrorist activity and retaliation and possible increase in future international conflicts. Investors and markets typically react negatively to uncertainty. However, the quick overthrow of the Iraqi regime may negate the effects of some of these factors (Leight, 2003).

Almost immediately after the prospects of war became inevitable, financial and economic analysts began predicting the price of oil could skyrocket well above $\$ 40$ per barrel. The effects of such a high price would have been potentially catastrophic for the world economy. High oil prices translate into a myriad of problems for 
consumers and businesses. Consumers must spend more on energy costs and gasoline for their cars. This results in a decrease in consumer net wealth and a decrease in consumer spending, which ultimately impacts the economy.

For businesses, the costs of transportation and shipping increases affect profits. In the airline industry, which has been plagued with red ink since the September 11 tragedy and even before, high oil prices would have exasperated the situation? Table I illustrates the effects of a $\$ 5$ increase per barrel on the real GDP of the United States and other industrialized countries (Richardson, 2003).

In the U.S., GDP would decrease by $0.3 \%$ in the first year alone. Consider the fact that in 2002 the GDP for the United States was approximately 10.6 trillion dollars. A $0.3 \%$ loss of GDP would be roughly equivalent to 32 billion dollars (Gross Domestic Product, 1 Decimal). However, two things happened to mitigate these factors. First, the Organization of Petroleum Exporting Countries (OPEC) pledged to increase production to keep the price of oil at a target of $\$ 25$ per barrel (Tulacz and Powers, 2003). Not only did this help logistically by physically producing more oil for consumption, but it also signal, to some degree, cooperation from the Middle East. The second thing that happened was a quick and successful campaign in Iraq. All of the speculation about a complicated and messy conflict in Baghdad never came to fruition. These two factors helped to improve expectations about crude oil futures and keep the price somewhat stabilized. In fact, oil prices peaked sometime in March at just below $\$ 40$ per barrel and then dropped sharply to around $\$ 30$ per barrel sometime around April as victory in Iraq became apparent.

The markets reacted accordingly and by early 2003, amid uncertainty of the conflict in Iraq, the Dow Jones Industrial Average (DJIA) dropped significantly. However, as the chart below indicates, the DJIA has steadily increased in value since mid March and has continued to a relative high of 9,204 in late July 2003. Although the stock market has not rebounded to the levels it attained in the latter part of the 1990's it has certainly been on trough phase from its low point in 2002 (DJ Indu Average, Figure I).

The last two years have been noted by a variety of major world and domestic events. The stock market bubble of the late 1990's, fueled by overconfidence and saturation in the technology sector, finally burst in 2000 . Against this backdrop of world events, the U.S. dollar has been steadily declining in value against the Euro. Since it's inception in 1999, the Euro has steadily fallen against the U.S. dollar and has disappointed the member nations of the European Monetary Union. Several reasons for this push to a unified European currency are stabilization of inflation and interest rates, stimulation of economic growth through removal of trade barriers, and the creation of a unified economy that could compete globally with the U.S. However, recently, the Euro has consistently fallen behind the dollar in value. The drop in dollar was due to factors such as a weak domestic and global economy, loss of confidence in the U.S. financial markets, and weak expansionary monetary policy.

As illustrated in Figure II, the U.S. dollar's decline, relative to the euro, began sometime between late 2001 and early 2002. Since that time the Euro has steadily been gaining value against the dollar. Overall, the decline in the value of the dollar can be attributed to two major factors, an aggressive expansionary monetary policy ${ }^{1}$ in the U.S. combined with a decline in demand for U.S. dollar denominated assets worldwide. The U.S. has been following an aggressive expansionary monetary policy to stamp off a second recession and possible deflation. The Fed has cut the Federal Funds interest rate thirteen times since January 1, 2001 to a 45 year low of one percent (Aversa, 2003). This cut in interest rates is expected to discourage consumers from saving and instead encourage them to spend. In additional, the weakness in the U.S. stock markets and recent scandals has caused investors worldwide to decrease demand for U.S. dollar denominated assets.

In late 2000, Iraq began selling its oil for Euros. Iran soon followed suit and converted the majority of its central bank reserve funds to euros. By late 2002, North Korea also started adopting the Euro as its standard currency of trade. These surplus dollars on the global market have contributed to the decline of the dollar. It has been speculated that if the Organization of Petroleum Exporting Countries (OPEC) cartel were to dump dollars in favor of euros for all of its oil transactions, it would lead to a massive devaluation of the dollar and spark a worldwide dumping of dollars. This could have disastrous effects on the U.S. economy (Butler, 2003).

\footnotetext{
${ }^{1}$ A form of stabilization policy consisting of an increase in the amount of money in circulation. This policy is designed to avoid or correct the problems associated with a business cycle contraction.
} 
A successful war in Iraq, coupled with the installation of a government sympathetic to the United States will have positive ramifications for the dollar. It will virtually guarantee that Iraq will once again fall back on the dollar as its currency of trade. U.S. control of Iraq will also undermine OPEC's hold over oil prices. With current development in Iraq, the U.S. could flood the world markets with oil. This will have two possible effects. First, it will drive down the price of oil worldwide and increase consumer purchasing power. Second, it will decrease the wealth of oil producing nations making a weak dollar relatively more attractive than the stronger Euro (Butler, 2003).

The dollar has had a strong reputation as the stable currency of choice and it is unlikely that its recent fall in value will lead to the scenario in which nations begin dumping the dollar in a panic. Although the Euros new found increase in value provides Europe with international purchasing power. Europe has been plagued with a sluggish economy, growing only $1 \%$ this year, and notoriously high unemployment. A strong euro makes domestic products more expensive for Europeans and makes products abroad, including U.S. products, more attractive. This could be just the boost the U.S. economy needs (Ewing, et al, 2003).

In the short run, a weak dollar will mean a decrease in the standard of living in the U.S. due to a sharp increase in the price of imports. However, in the long run a weak dollar will jump-start the economy as demand for cheaper U.S. goods increases exports abroad. Increased domestic sales and international sales, due to a disparity between the dollar and the euro, will ultimately decrease domestic unemployment and increase the value of the stock markets. U.S. based multinational firms stand to profit as well. This increase in sales has been attributed to foreign currency translation and not necessarily due to increase in the demand for burgers and fries. This could lead to drastic growth in the U.S. economy (Miller et al, 2003).

\section{CONCLUSION}

The decision to invade Iraq will undoubtedly be debated for many years. The majority of the nations in the world opposed the decision and it is difficult to predict the ramifications of this decision. In the short run it has caused some damage between the United States and some of its most important trading partners globally. Consumers, both in the U.S. and abroad, have called for boycotts against U.S. products and against the products of those countries that opposed the United States. War in Iraq has also caused fluctuations in oil prices and discouraged investment in financial markets. However, these effects seem to have been relatively limited in scope and longevity. While war in Iraq certainly did not help improve the image of the U.S. abroad, it seems that a chronically sluggish world economy has overshadowed any potential backlash that the U.S. could have experienced. Additionally a weakening dollar may also be instrumental in reversing some of the endemic trade imbalances that the U.S. typically experiences. In the long run the effects of the war in Iraq may be nothing more than a bump in the road in an already complicated economic geography.

Table I: Oil Price Increase Of \$5 Per Barrel

\begin{tabular}{llll}
\hline \multicolumn{4}{c}{ Effects on real GDP $(\%)$} \\
\hline
\end{tabular}

Source: U.S./Euro Foreign Exchange Rate. Economic Research. Federal Reserve

Bank of St. Louis. 01August2003 
Figure 1: The Dow Jones Industrial Average (Djia) Between September 2002-July 2003

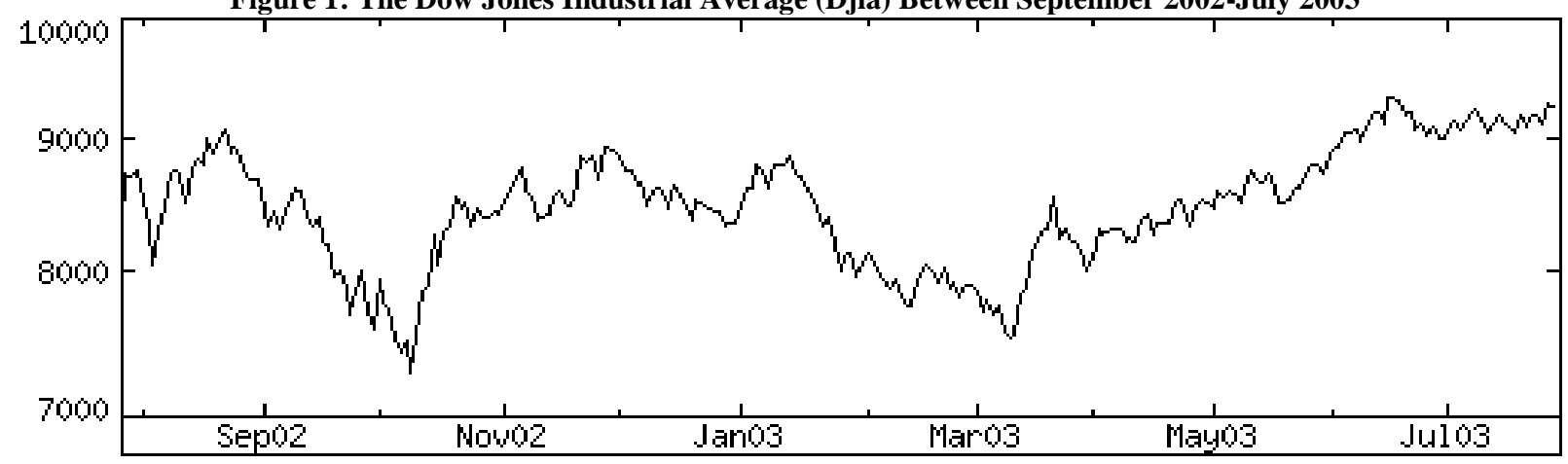

Source: Crude Oil (light, NYMEX) Weekly Price. TFC Commodity Charts. 1 August 2003.

Figure II: United States-Euro Foreign Exchange Rate (U.S. Dollar One Euro)

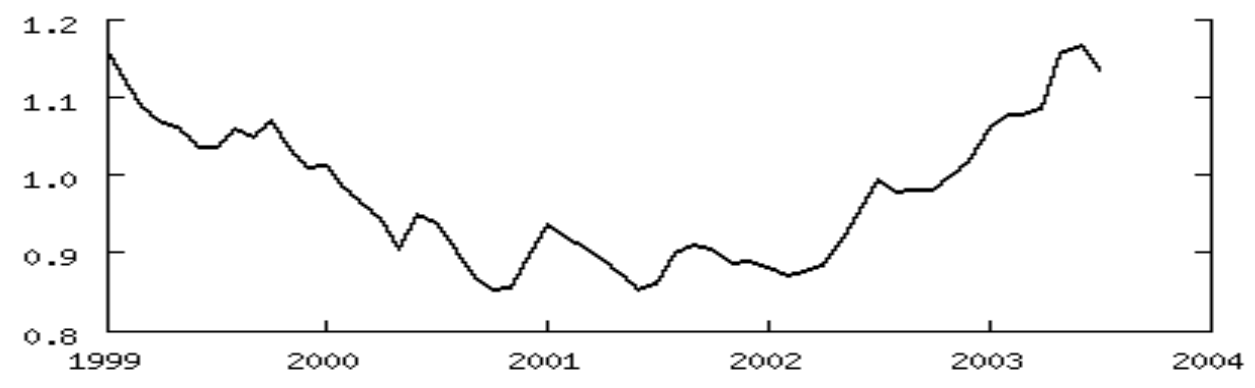

Source: DJ Indu Average, Basic Chart. Yahoo Finance. 2 August 2003.

\section{REFERENCE}

1. Aversa, Jeannine. Low Interest Rates Cut Greenspan Earnings. Associated Press. http://wwwCentredaily. com . Posted 19 July, 2003. Accessed 3 August 2003. http://www.centredaily.com/mld/centredaily/ Business/6341381.htm

2. $\quad$ Butler, Amir. The Euro and the War on Iraq. 29 March 2003. A True Word. 2 August 2003. http://www.atrueword.com/index.php.article/articleprint/49/-1/1.

3. Ewing, Jack, et al. Beware the Super Euro. Business Week 19 May 2003: Issue 3833, p52. Academic Search Premier. EBSCOhost. UHD Lib., Houston. 26 June 2003. http://www.ebscohost.com.

4. Francis, David R. Global Rifts Deep as Economies Sag. Christian Science Monitor 30 May 2003: Vol. 95, Issue 129, p1. Academic Search Premier.

5. Graff, James and Anthee Carassava. Can France Put a Cork In It? Time Europe 28 April 2003:Vol. 161 Issue 17, p42. Academic Search Premier. EBSCOhost. UHD Lib., Houston. 26 July 2003. http://www.ebscohost.com.

6. Gross Domestic Product, 1 Decimal. 31 July 2003. Economic Research. Federal Reserve Bank of St. Louis. 01 August 2003. http://research.stlouisfed.org/fred2/series/GDP/18.

7. Leight, Andrew, Justin Wolfers, and Eric Zitzewitz. What do Financial Markets Think of War. Stanford University. Updated 17 March 2003. Accessed 1 August 2003. http://faculty-gsb.stanford.edu/zitzewitz /Research/iraq.pdf.

8. Mandell, Michael J., et al. How War Will Reshape the Economy. Business Week 14 April 2003: Issue 3828, p28. Academic Search Premier. EBSCOhost. UHD Lib., Houston.26 July 2003. http://www.ebscohost.com 
9. Miller, Rich, et al. Good News! The Dollar is Down. Business Week Online 16 May 2003. Academic Search Premier. EBSCOhost. UHD Lib., Houston. 26 July 2003. http:www.ebscohost.com.

10. Richardson, David. Economics of War with Iraq. Current Issues Brief No 21 2002-3.24 March 2003. Department of the Parliamentary Library. 01 August 2003. http://www.aph.gov.au/library/pubs/CIB/200203/03cib20.htm.

11. Tulacz, Gary J. and Mary B. Powers. Global Political and Business Turmoil Takes a Toll on International Revenue. Engineering News-Record, May 2003: Vol. 250 Issue 19, P79. Academic Search Premier.

12. U.S. International Transactions. BEA International Economic Accounts. 19 June 2003. Accessed 28 June 2003. 